\title{
Experiential Learning untuk Meningkatkan Kompetensi Multikultural Mahasiswa
}

\author{
Mawardi Djamaluddin', Blasius Boli Lasan², Adi Atmoko² \\ 'Program Studi Bimbingan dan Konseling Pendidikan Islam, Fakultas Tarbiyah dan Ilmu Keguruan, \\ Institut Agama Islam Negeri Ternate, Jl. Lumba-Lumba, Ternate, Maluku Utara, Indonesia 97727 \\ ${ }^{2}$ Jurusan Bimbingan dan Konseling, Fakultas Ilmu Pendidikan, Universitas Negeri Malang, \\ Jl. Semarang No. 5, Malang, Jawa Timur, Indonesia 65145 \\ E-mail: mawardidjamaluddin@gmail.com
}

Artikel diterima: 18 April 2018; direvisi: 15 Oktober 2018; disetujui: 26 Oktober 2018

\begin{abstract}
The study aims at measuring the effectiveness of experiential learning model for improving the multicultural competence of non-Javanese students in the Malang City. The true-experiment type quantitative study is conducted by using the pretest-posttest control group design. The subjects were 20 non-Javanese students in several universities in Malang City that had low multicultural competence. The Wilcoxon Signed Rank Test was implemented in order to compare the score of the students before and after the treatment. In addition, Mann-Whitney U Test was also implemented in order to compare the level of effectiveness statistically between the control group and the experimental group after the provision of the treatment. The results of the study show that the experimental group has significant mean score of multicultural competence in comparison to the control group. The statement implies that the experiential learning model has been effective in improving the multicultural competence of non-Javanese students.
\end{abstract}

Keywords: multicultural competence; non-Javanese students; experiential learning model

\begin{abstract}
Abstrak: Penelitian ini bertujuan untuk mengukur keefektifan model experiential learning dalam meningkatkan kompetensi multikultural mahasiswa luar Jawa di Kota Malang. Penelitian kuantitatif dengan jenis true experiment ini menggunakan desain pretest-posttest control group design. Subjek penelitian adalah 20 mahasiswa luar Jawa pada beberapa Perguruan Tinggi di Kota Malang yang memiliki kategori kompetensi multikultural rendah. Teknik analisis data yang digunakan adalah Wilcoxon Signed Rank Test untuk mengukur perbandingan skor sebelum dan sesudah diberikan perlakuan. Analisis Mann-Whitney $U$ Test digunakan untuk membandingkan tingkat keefektifan secara statistik antara kelompok eksperimen dan kelompok kontrol sesudah diberikan perlakuan. Hasil yang menunjukkan peningkatan nilai rata-rata kompetensi multikultural secara signifikan pada kelompok eksperimen dibandingkan dengan kelompok kontrol menunjukkan bahwa model experiential learning efektif untuk meningkatkan kompetensi multikultural mahasiswa luar Jawa.
\end{abstract}

Kata kunci: kompetensi multikultural; mahasiswa luar Jawa; model experiential learning

Indonesia adalah negara yang memiliki 14.572 pulau yang dihuni oleh 1.340 suku yang menggunakan 742 bahasa daerah yang beragam (Rustanto, 2015). Banyaknya jumlah suku dan beragamnya bahasa daerah telah menstimulasi kondisi demografis masyarakat Indonesia yang beragam dalam konteks budaya atau yang lebih dikenal dengan kondisi multikultural. Kondisi multikultural tidak hanya dipengaruhi oleh keragaman etnis; ras; latar belakang budaya; letak geografis; dan asal daerah semata, namun diperluas menjadi beberapa variabel lain yang meliputi: kondisi fisik; usia; keragaman sosial ekonomi; agama; karakteristik pribadi; kemampuan sosial; perilaku dan kebiasaan 
serta kemampuan intelektual (Sue, 1991). Kondisi multikultural pada suatu daerah juga dapat dipengaruhi oleh beberapa faktor, yaitu: kemajuan teknologi; pembangunan sosial-ekonomi yang belum merata; kemudahan aksesibilitas dalam berpindah dari satu kota ke kota lainnya; dan kualitas pendidikan di wilayah tersebut.

DiMalang, kondisimasyarakat multikultural dipengaruhioleh meningkatnya kualitas pendidikan. Berdirinya beberapa Perguruan Tinggi ternama yang berskala nasional telah meningkatkan animo calon mahasiswa dari berbagai daerah di Indonesia untuk melanjutkan pendidikan di Kota Malang. Fenomena inilah yang meningkatkan interaksi multikultural antara mahasiswa dengan latar belakang budaya yang berbeda. Berdasarkan kultur, secara sempit mahasiswa di Kota Malang dapat dibagi menjadi dua, yaitu mahasiswa Jawa dan mahasiswa luar Jawa. Mahasiswa Jawa adalah mahasiswa yang berasal dari pulau Jawa dan memiliki karakteristik latar belakang budaya Jawa (terutama Jawa Tengah dan Jawa Timur yang identik dengan suku Jawa), sedangkan mahasiswa luar Jawa merujuk pada mahasiswa yang berasal dari luar pulau Jawa dan memiliki karateristik latar belakang selain budaya Jawa (terutama mahasiswa yang berasal dari etnis Lombok; Makassar; Maluku; dan Papua). Ditinjau dari segi interaksi, ada perbedaan model interaksi antara mahasiswa Jawa dan luar Jawa, di mana mahasiswa luar Jawa cenderung bersifat homogenitas (Damayanti \& Kusumo, 2017). Homogenitas dalam interaksi ini disebabkan adanya rasa aman mahasiswa luar Jawa ketika berinteraksi dengan mahasiswa yang sesuku, oleh karena itu interaksi yang bersifat dinamis antara masyarakat multikultural perlu dikelola.

Interaksi dalam masyarakat multikultural yang bersifat dinamis perlu dikelola secara efektif untuk meningkatkan relasi yang baik antara individu/kelompok yang berbeda budaya. Ketika kondisi multikultural tidak mampu dikelola dengan baik maka akan terjadi pertentangan budaya. Proses interaksi beda budaya dapat berlangsung dengan efektif ketika setiap individu/kelompok mampu menyadari keunikan karakteristik budaya yang dimiliki dan keunikan dari budaya lain yang perlu dihargai. Berkenaan dengan kesadaran terhadap keunikan budaya yang dimiliki, sebuah konsep dari kompetensi multikultural merupakan variabel penting yang perlu dirumuskan dan dimiliki oleh individu. Kompetensi multikultural yang dirumuskan terdiri dari tiga komponen yaitu: kesadaran (awareness); pengetahuan (knowledge); dan keterampilan (skills) baik dalam perspektif budaya sendiri ataupun budaya lain (Pedersen, 2000).

Berdasarkan hasil studi pendahuluan melalui proses wawancara dengan tiga perwakilan mahasiswa dari etnis budaya Jawa dan tiga perwakilan mahasiswa dari etnis budaya luar Jawa, yang berdomisili di Kota Malang, diperoleh gambaran bahwa tidak semua mahasiswa luar Jawa memiliki kompetensi multikultural yang memadai. Tidak dimilikinya kompetensi multikultural, terutama dalam dua konteks situasi yang dihadapi yaitu adanya beberapa pola perilaku budaya dari mahasiswa luar Jawa yang tidak sesuai dengan nilai-nilai budaya masyarakat setempat (masyarakat Kota Malang) dan terbatasnya pengetahuan yang dimiliki terhadap norma (etika sopan santun) yang berlaku dalam budaya Jawa di Kota Malang.

Pentingnya peningkatan kompetensi multikultural relevan dengan pandangan Reynolds \& Pope (1994) yang menekankan bahwa setiap Perguruan Tinggi perlu mengarahkan upaya yang lebih terhadap pengembangan sensitivitas multikultural dan memberikan penguatan terhadap lingkungan akademik yang mendukung, dengan penerapan nilai-nilai sosiokultural dalam kegiatan dan program yang dilakukan sebagai apresiasi terhadap perbedaan budaya. Rendahnya kompetensi multikultural juga dialami oleh individu/kelompok yang memiliki kemampuan adaptasi sosial rendah terhadap lingkungan sosiokultural yang baru dan meneguhkan sikap eksklusivisme dalam pergaulan atau hanya membatasi diri untuk bergaul dengan orang-orang dari latar belakang budaya yang sama serta cenderung menilai sesuatu hal berdasarkan perspektif budaya yang dimiliki. Kompetensi multikultural dan sensitivitas budaya memang sangat penting dikembangkan oleh individu yang terjebak dalam ketidaksadaran dari bias etnosentrisme (Sabnani, Ponterotto, \& Borodovsky, 1991).

Pada dua Perguruan Tinggi di Kota Malang ditemukan persentase mahasiswa Jawa di Universitas Muhammadiyah Malang sebesar $60 \%$, sedangkan mahasiswa luar Jawa sebasar $40 \%$, di Universitas Negeri Malang, persentase mahasiswa Jawa sebesar 70\%, sedangkan mahasiswa luar Jawa sebesar 
30\%. Data ini menunjukkan bahwa kondisi multikultural di dua Perguruan Tinggi di kota Malang ini relatif cukup tinggi dan diperlukan perhatian secara khusus oleh pemangku kepentingan dalam memfasilitasi tercapainya proses adaptasi mahasiswa luar Jawa secara optimal.

Hasil wawancara terhadap tiga Perguruan Tinggi Negeri yang berada di Kota Malang menggambarkan bahwa Perguruan Tinggi pada umumnya belum secara khusus memprogramkan kegiatan peningkatan kompetensi multikultural kepada mahasiswa baru dari latar belakang budaya yang berbeda dengan kondisi masyarakat di sekitar institusi pendidikan. Program kegiatan peningkatan kompetensi multikultural hanya terbatas pada kajian konseptual, sedangkan program yang menekankan pada keterlibatan mahasiswa untuk meningkatkan kemampuan adaptasi sosial cenderung jarang dilaksanakan. Kegiatan peningkatan kompetensi multikultural cenderung dilaksanakan dalam format seminar ataupun kegiatan penguatan aspek kognitif semata. Sementara itu, peningkatan kompetensi multikultural perlu dilakukan secara terintegrasi dengan keterlibatan langsung individu dalam lingkungan yang berbeda budaya agar individu mampu secara komprehensif memperoleh pengalaman tentang perilaku yang tepat dalam berinteraksi dengan orang-orang yang berbeda budaya.

Berdasarkan survei dari anggota American Counseling Association, tingkat kemampuan konselor dalam memberikan pelatihan multikultural kepada konseli dapat dikategorikan tidak memadai karena metode pelatihan yang digunakan cenderung menghasilkan kompetensi pada domain kognitif saja, tanpa berpengaruh secara signifikan pada domain pengalaman (experiential) dan emosi (HolcombMcCoy \& Myers, 1999). Salah satu pendekatan yang dipandang relevan dan dapat digunakan secara efektif untuk memfasilitasi peningkatan kompetensi multikultural mahasiswa luar Jawa adalah model experiential learning. Model experiential learning adalah pembelajaran yang melibatkan keseluruhan aspek psikologis individu dengan mengalami kondisi tertentu melalui simulasi atau dalam latar dunia nyata (Downs, 1992). Model experiential learning dipilih sebagai pendekatan yang digunakan untuk meningkatkan kompetensi multikultural karena sesuai dengan asumsi bahwa peningkatan kompetensi multikultural individu menuntut keterlibatan individu dengan pengalaman dalam berinteraksi dengan orang-orang dari beragam latar belakang budaya secara kontekstual.

Sebuah hasil penelitian menunjukkan bahwa pelatihan peningkatan kompetensi multikultural pada jenjang dewasa awal dapat dicapai secara optimal jika individu diberikan kesempatan untuk berinteraksi langsung dengan masyarakat dari kelompok budaya tertentu (Arswimba, 2016; Riskiyah, 2014). Penerapan model experiential learning untuk meningkatkan kompetensi multikultural dalam penelitian ini diimplementasikan dalam format kelompok psikoedukasi berdasarkan pertimbangan bahwa perlakuan yang diberikan dalam penelitian ini diformulasikan dalam bentuk kegiatan pelatihan. Selain itu, kelompok psikoedukasi juga menekankan dua fungsi utama dalam layanan bimbingan dan konseling yaitu fungsi pencegahan (preventif) dan fungsi pengembangan (developmental). Adapun penelitian ini bertujuan untuk menguji keefektifan model experiential learning untuk meningkatkan kompetensi multikultural mahasiswa luar Jawa di Kota Malang.

\section{METODE}

Penelitian ini merupakan penelitian kuantitatif dengan menggunakan rancangan experimental design. Secara khusus, desain eksperimen yang digunakan adalah true experimental design. Bentuk desain penelitian yang digunakan dalam penelitian ini adalah pretest-posttest control group design. Tahap penelitian dilakukan dalam tiga fase yang terdiri dari: fase sebelum diberikan perlakuan dengan menjaring subjek penelitian menggunakan skala kompetensi multikultural, fase selama proses perlakuan dengan menggunakan pengamatan (observasi) terhadap perilaku subjek penelitian selama proses perlakuan, dan fase setelah diberikan perlakuan melalui pengisian Skala Kompetensi Multikultural untuk mengukur peningkatan skala kompetensi multikultural subjek penelitian. Rincian setiap tahap dalam penelitian disajikan pada tabel 1.

Instrumen utama yang digunakan adalah Skala Kompetensi Multikultural yang terdiri dari 63 butir yang telah melalui uji validitas dan reliabilitas. Uji validitas dan reliabilitas dilakukan dengan melibatkan 40 mahasiswa luar Jawa yang tersebar pada tiga Perguruan Tinggi Negeri di Kota 
Tabel 1 Tahapan Penelitian

\begin{tabular}{|c|c|c|}
\hline Tahap & Kelompok Eksperimen & Kelompok Kontrol \\
\hline $\begin{array}{l}\text { Sebelum } \\
\text { diberikan } \\
\text { perlakuan }\end{array}$ & $\begin{array}{l}\text { 1. Penentuan subjek penelitian yang di } \\
\text { tempatkan dalam kelompok eksperimen } \\
\text { dari Ikatan Pelajar Mahasiswa-Maluku } \\
\text { Utara di Kota Malang (IPMA-MUM) } \\
\text { 2. Pelaksanaan pretest kepada 82 } \\
\text { mahasiswa menggunakan Skala } \\
\text { Kompetensi Multikultural, diperoleh } \\
\text { sepuluh mahasiswa yang memiliki } \\
\text { kompetensi multikultural rendah, } \\
\text { sepuluh mahasiswa ini dipilih sebagai } \\
\text { subjek penelitian pada kelompok } \\
\text { eksperimen }\end{array}$ & $\begin{array}{l}\text { 1. Penentuan subjek penelitian yang di } \\
\text { tempatkan dalam kelompok kontrol dari } \\
\text { Forum Komunikasi Mahasiswa Tidore - } \\
\text { Malang (FKMT-Malang) } \\
\text { 2. Pelaksanaan pretest kepada } 33 \\
\text { mahasiswa menggunakan Skala } \\
\text { Kompetensi Multikultural, diperoleh } \\
\text { sepuluh mahasiswa yang memiliki } \\
\text { kompetensi multikultural rendah, } \\
\text { sepuluh mahasiswa ini dipilih sebagai } \\
\text { subjek penelitian pada kelompok } \\
\text { kontrol }\end{array}$ \\
\hline $\begin{array}{l}\text { Selama } \\
\text { proses } \\
\text { perlakuan }\end{array}$ & $\begin{array}{l}\text { Kegiatan pelatihan kompetensi } \\
\text { multikultural yang terdiri dari sembilan } \\
\text { pertemuan mengarah pada peningkatan } \\
\text { kompetensi multikultural dalam konteks: } \\
\text { menyadari; mengetahui; dan terampil } \\
\text { dalam konteks gaya berkomunikasi; } \\
\text { penggunaan bahasa daerah; pengaruh mitos } \\
\text { (sejarah budaya); orientasi nilai; norma } \\
\text { yang berlaku; dan simbol-simbol baik } \\
\text { berkaitan dengan budaya asal dan budaya } \\
\text { Jawa, dengan perincian kegiatan: } \\
\text { 1. Pertemuan I: pembentukkan kelompok } \\
\text { 2. Pertemuan II: membahas topik tentang } \\
\text { Menyadari keunikan karakteristik } \\
\text { budaya asal } \\
\text { 3. Pertemuan III: membahas topik tentang } \\
\text { Mengenal lebih dekat budaya asal yang } \\
\text { dimiliki } \\
\text { 4. Pertemuan IV: membahas topik tentang } \\
\text { Keterampilan berkomunikasi dalam } \\
\text { budaya asal } \\
\text { 5. Pertemuan V: membahas topik tentang } \\
\text { Menyadari karakteristik budaya Jawa } \\
\text { 6. Pertemuan VI: membahas topik tentang } \\
\text { Mengetahui karakteristik budaya Jawa } \\
\text { 7. Pertemuan VII: mempraktikkan } \\
\text { keterampilan berkomunikasi dalam } \\
\text { budaya Jawa } \\
\text { 8. Pertemuan VIII: mengimplementasikan } \\
\text { kompetensi multikultural dalam } \\
\text { kehidupan sehari-hari }\end{array}$ & $\begin{array}{l}\text { Kegiatan peningkatan kompetensi } \\
\text { multikultural dilaksanakan berdasarkan } \\
\text { program kerja yang telah dirancang dalam } \\
\text { Forum Komunikasi Mahasiswa Tidore - } \\
\text { Malang (FKMT-Malang) dengan memuat } \\
\text { dua kegiatan utama: } \\
\text { 1. Orientasi mahasiswa baru, yang } \\
\text { memiliki fokus kegiatan untuk } \\
\text { memberikan pengetahuan kepada } \\
\text { mahasiswa baru tentang pola } \\
\text { perkuliahan dan cara berinteraksi } \\
\text { dengan orang-orang di lingkungan } \\
\text { kampus. } \\
\text { 2. Kegiatan kunjungan organisasi, yang } \\
\text { memuat kegiatan berupa kunjungan } \\
\text { ke beberapa organisasi mahasiswa } \\
\text { di Kota Malang dalam rangka } \\
\text { menggali informasi tentang pola } \\
\text { interaksi organisasi mahasiswa dengan } \\
\text { masyarakat di sekitarnya }\end{array}$ \\
\hline $\begin{array}{l}\text { Setelah } \\
\text { diberikan } \\
\text { perlakuan }\end{array}$ & $\begin{array}{l}\text { Pelaksanaan posttest kepada } 10 \text { subjek } \\
\text { penelitian dan menutup kegiatan pelatihan } \\
\text { (terminasi). Instrumen yang digunakan } \\
\text { adalah Skala Kompetensi Multikultural. }\end{array}$ & $\begin{array}{l}\text { Pelaksanaan posttest kepada } 10 \text { subjek } \\
\text { penelitian dan menutup kegiatan pelatihan } \\
\text { (terminasi). Instrumen yang digunakan } \\
\text { adalah Skala Kompetensi Multikultural }\end{array}$ \\
\hline
\end{tabular}

Malang. Jumlah butir sebelum uji validitas dan reliabilitas berjumlah 82 butir dan sesudah dilakukan analisis validitas dan relibilitas maka diperoleh 63 butir yang valid. Nilai validitas yang diperoleh pada 63 butir berada pada rentang skor 0,292 sampai dengan 0,696, hal ini menunjukkan bahwa seluruh butir memenuhi kriteria validitas karena memperoleh skor dengan kategori $\geq 0,3$. Sementara itu, reliabilitas skala kompetensi multikultural memiliki nilai sebesar 0,923, hal ini menunjukkan bahwa keajegan dari skala ini tergolong tinggi dan dapat digunakan untuk mengukur kompetensi multikultural mahasiswa luar Jawa. 
Proses penelitian dilaksanakan di Asmara Paguyuban Ikatan Pelajar Mahasiswa - Maluku Utara di Kota Malang (IPMA-MUM) dengan melibatkan 115 mahasiswa luar Jawa pada jenjang pendidikan semester tiga dengan rincian: 82 mahasiswa luar Jawa yang tergabung dalam Ikatan Pelajar Mahasiswa - Maluku Utara di Kota Malang (IPMA-MUM) dan 33 mahasiswa luar Jawa yang tergabung dalam Forum Komunikasi Mahasiswa Tidore-Malang (FKMT-Malang). Teknik pemilihan sampel yang digunakan adalah purposive sampling. Penetapan subjek penelitian didasarkan pada hasil studi pendahuluan yang menemukan bahwa mahasiswa luar Jawa yang teridentifikasi memiliki ciri atau karakteristik kompetensi multikultural rendah yang meliputi: membatasi pergaulan hanya dengan teman-teman yang berasal dari daerah yang sama; adanya stereotip kepada kelompok budaya lain; mengalami hambatan dalam beradaptasi dengan lingkungan budaya baru (budaya Jawa); dan mengalami hambatan dalam berkomunikasi dengan teman yang berbeda budaya. Adapun tiga kriteria interpretasi hasil dari perhitungan skala kompetensi multikultural yaitu: (1) Tinggi dengan rentang skor 213-315; (2) Sedang dengan rentang skor 147-230; dan (3) Rendah dengan rentang skor 63-146.

Setelah melalui proses pengukuran awal menggunakan Skala Kompetensi Multikultural yang disebar kepada populasi penelitian, teridentifikasi 20 mahasiswa luar Jawa yang memiliki tingkat kompetensi multikultural rendah dan ditetapkan sebagai subjek penelitian. Subjek penelitian selanjutnya dibagi ke dalam dua kelompok, yaitu sepuluh subjek pada kelompok eksperimen dan sepuluh subjek pada kelompok kontrol. Sebelum pelaksanaan kegiatan eksperimen, tahapan penelitian dilakukan dengan melakukan uji beda untuk menentukan bahwa tidak terdapat perbedaan kompetensi multikultural yang dimiliki oleh subjek dalam kedua kelompok.

Uji hipotesis dilakukan menggunakan Mann-Whitney U Test dengan bantuan program SPSS IBM Statistics 16.0 untuk mengukur perbedaan nilai sebelum (pretest) dan sesudah (posttest) diberi perlakuan. Sebelum melalui proses analisis Mann-Whitney U Test, proses analisis terlebih dahulu dilakukan dengan Wilcoxon Signed Rank Test untuk mengukur perbedaan nilai sebelum (pretest) diberikan perlakuan dan sesudah (pretest) diberikan perlakuan pada kelompok kontrol dan kelompok eksperimen. Data yang bersifat kualitatif berkenaan dengan kemampuan siswa dalam merespon melalui argumentasi yang tepat dijadikan sebagai data pendukung untuk menentukan memperkuat peningkatan kompetensi multikultural dari subjek penelitian, hal ini bertujuan untuk memberikan gambaran secara komprehensif dalam setiap aspek yang dinilai.

\section{HASIL}

\section{Deskripsi Data Hasil Pretest}

Pretest dilakukan dengan menggunakan Skala Kompetensi Multikultural untuk menilai kondisi aktual dari tingkat kompetensi multikultural subjek penelitian sebelum diberi perlakuan. Rerata skor konversi kelompok eksperimen 142,2 dan rerata konversi kelompok kontrol dengan skor 143,3 dengan kategori rendah.

Proses penjaringan subjek penelitian dari populasi pada kelompok eksperimen dan kelompok kontrol menunjukkan bahwa populasi penelitian pada kelompok eksperimen dan kelompok kontrol sebagian besar memiliki tingkat kompetensi multikultural dalam kategori sedang yaitu $56(68,29 \%)$ pada kelompok eksperimen dan 18 (54,54\%) pada kelompok kontrol.

Subjek penelitian yang dipilih lebih difokuskan pada populasi penelitian yang memiliki tingkat kompetensi multikultural berada pada kategori rendah yaitu $16(19,51 \%)$ pada kelompok eksperimen dan sepuluh $(30,30 \%)$ kelompok kontrol, hal ini dilakukan dengan mempertimbangkan bahwa teknik sampling yang digunakan adalah purposive sampling. Selain itu, subjek penelitian yang berada pada kategori rendah diasumsikan memiliki kompetensi multikultural yang rendah dalam seluruh komponennya. Komponen tersebut terdiri dari: kesadaran; pengetahuan; dan keterampilan multikultural. Pemaparan data dari persentase penjaringan subjek penelitian secara lengkap disajikan pada tabel 2. 
Tabel 2 Persentase Penjaringan Subjek Penelitian

\begin{tabular}{cccccc}
\hline \multicolumn{3}{c}{ Kelompok Eksperimen } & \multicolumn{3}{c}{ Kelompok Kontrol } \\
\hline Jumlah Populasi & Persentase & Kategori & Jumlah Populasi & Persentase & Kategori \\
\hline \multirow{2}{*}{82} & $10(12,19 \%)$ & Tinggi & & $5(15,51 \%)$ & Tinggi \\
& $56(68,29 \%)$ & Sedang & 33 & $18(54,54 \%)$ & Sedang \\
& $16(19,51 \%)$ & Rendah & & $10(30,30 \%)$ & Rendah \\
\hline
\end{tabular}

\section{Deskripsi Peningkatan Kompetensi Multikultural Selama Perlakuan}

Peningkatan kompetensi multikultural terlihat secara empiris berdasarkan hasil mendeskripsikan peningkatan kompetensi multikultural dalam tiga komponen yang meliputi: kesadaran multikultural; pengetahuan multikultural; dan keterampilan multikultural dalam perspektif budaya asal subjek penelitian dan juga budaya Jawa.

\section{Kesadaran Terhadap Budaya Asal}

Pada tahap ini trainer memfasilitasi subjek penelitian untuk merefleksikan kembali hasil pengamatan yang telah dilakukan oleh subjek penelitian (reflective observation) terhadap pola interaksi budaya terutama dalam latar budaya asal (concrete experience). Pada awal kegiatan, subjek penelitian diberikan penjelasan singkat mengenai cara mengenal budaya Nusantara. Setelah itu, subjek penelitian diajak untuk melakukan cultural self-reflections atau menggali pengalaman dalam budaya asal yang berkaitan dengan keunikan budaya yang dimiliki dalam konteks gaya/ cara berkomunikasi dalam budaya asal; penggunaan bahasa daerah dalam budaya asal; pengaruh mitos (sejarah budaya asal); orientasi nilai budaya asal; norma yang berlaku dalam budaya asal dan simbol-simbol budaya asal.

Dalam pertemuan ini, subjek penelitian sangat antusias dan memberikan perhatian secara penuh, beberapa subjek penelitian pada awalnya tidak mampu mendeskripsikan secara tepat keunikan karakteristik budaya asal yang dimiliki, sehingga asumsi awal yang dapat diberikan adalah sebagian besar subjek penelitian memiliki kesadaran multikultural yang rendah terhadap karakteristik budaya asal.

Setelah memanfaatkan dinamika dalam diskusi kelompok, sebagian besar subjek penelitian mulai mampu menyadari karakteristik budaya asal yang dimiliki. Setelah mendapat stimulasi dari trainer dengan mengajukan beberapa pertanyaan evokatif, beberapa subjek penelitian yang pada awalnya belum secara optimal mampu memaknai faktor-faktor yang memengaruhi keunikan budaya asalnya, mampu mendeskripsikan pemaknaan yang diperoleh terhadap keunikan budaya asal yang dimiliki. Secara umum, sebagian besar subjek penelitian memaknai bahwa keunikan budaya dimiliki oleh setiap orang walaupun dalam wilayah geografis yang sama.

\section{Mengetahui Karakteristik Budaya Asal}

Tujuan utama dalam tahap ini adalah meningkatkan pengetahuan subjek penelitian terhadap karakteristik budaya asal yang meliputi: gaya/cara berkomunikasi dalam budaya asal; penggunaan bahasa daerah dalam budaya asal; pengaruh mitos (sejarah budaya asal); orientasi nilai budaya asal; norma yang berlaku dalam budaya asal dan simbol-simbol budaya asal. Langkah-langkah peningkatan pengetahuan subjek penelitian terhadap kerakteristik budaya asal dilakukan melalui tahap abstract conceptualization. Pada tahap abstract conceptualization, subjek penelitian difasilitasi untuk mendefinisikan secara konseptual karakteristik budaya asal yang dimiliki berdasarkan hasil pengalaman dan pengamatan yang telah dilakukan pada tahap reflective observation dan concrete experience.

Hasil yang diperoleh adalah sebagian besar subjek penelitian tidak mampu mendeksripsikan faktor-faktor penyebab perilaku berbasis budaya dapat terjadi, hal ini dipengaruhi oleh kurangnya rutinitas membaca dan mengkaji tentang budaya asal. Walaupun demikian, dengan memanfaatkan 
kesamaan karakteristik subjek penelitian yang berasal dari latar belakang geografis yang sama dan pengetahuan yang dimiliki oleh beberapa subjek penelitian, maka sebagian subjek penelitian dapat mengkonstruksi pengetahuan yang dimiliki tentang karakteristik budaya asalnya.

\section{Terampil Berkomunikasi dalam Budaya Jawa}

Tahap ini bertujuan untuk meningkatkan keterampilan komunikasi multikultural subjek penelitian dalam berkomunikasi atau berinteraksi dengan orang-orang dari latar belakang budaya yang sama dengan memerhatikan beberapa hal penting, yaitu kesesuaian gaya komunikasi yang digunakan dalam konteks budaya asal dan mampu membina hubungan empatik serta memberikan umpan balik secara akurat.

Berdasarkan laporan dari subjek penelitian setelah melakukan praktik komunikasi dengan teman-teman dari budaya asal diluar latar kegiatan pelatihan, secara umum subjek penelitian tidak menghadapi kendala berarti dalam berkomunikasi dengan menerapkan gaya komunikasi yang sesuai dengan budaya asalnya dan juga mampu memberikan umpan balik dalam berkomunikasi, namun belum dapat membina hubungan empatik secara baik karena subjek penelitian belum mampu secara merespon secara akurat perasaan yang dimiliki oleh lawan bicara.

\section{Menyadari Karakteristik Budaya Jawa}

Tahap ini bertujuan untuk meningkatkan kesadaran subjek penelitian sebagai mahasiswa luar Jawa untuk menyadari karakteristik budaya Jawa yang meliputi: kesadaran terhadap gaya/cara berkomunikasi; penggunaan bahasa daerah; pengaruh mitos (sejarah budaya); orientasi nilai; norma yang berlaku; dan simbol-simbol budaya dalam perspektif budaya Jawa. Menyadari karakteristik budaya Jawa melibatkan dua tahapan dalam model experiential yaitu concrete experience dan reflective observation. Pada tahap concrete experience, subjek penelitian diarahkan untuk memperoleh pengalaman beda budaya dengan mengingat atau menceritakan kembali pengalaman beda budaya yang dialami secara konkrit dengan melibatkan proses penginderaan dan keterlibatan secara langsung dalam sebuah peristiwa yang terjadi. Pada tahap reflective observation, subjek penelitian mendeskripsikan kembali pengalaman yang dialami atau diamati dalam berinteraksi dengan masyarakat Jawa dan memberikan penilaian terhadap apa yang diamati tersebut. Subjek penelitian juga diharapkan mampu meniru perilaku tertentu dari budaya Jawa dan menilai seberapa efektif perilaku tersebut diterapkan.

Subjek penelitian pada awalnya mendeskripsikan bahwa mengalami beberapa pengalaman beda budaya yang menghambat komunikasi dengan teman-teman mahasiswa Jawa karena keterbatasan dalam mengenal dan mengidentifikasi perbedaan aspek-aspek antara budaya asalnya dan budaya Jawa. Setelah melalui tahapan diskusi untuk membahas pengamatan reflektif terhadap perbedaan pola perilaku budaya Jawa yang berbeda dengan budaya asal, subjek penelitian mampu mengenali dan menjelaskan letak perbedaannya. Perbedaan tersebut meliputi gaya/cara berkomunikasi; penggunaan bahasa daerah; pengaruh mitos (sejarah budaya); orientasi nilai; norma yang berlaku; dan simbol-simbol budaya dalam perspektif budaya Jawa. Kesadaran subjek penelitian terhadap keunikan budaya Jawa semakin diperkuat dengan menghadirkan pemateri yang membahas informasi tentang karakteristik budaya Jawa di Kota Malang.

\section{Mengetahui Karakteristik Budaya Jawa}

Tahap ini bertujuan untuk meningkatkan pengetahuan subjek penelitian tentang karateristik budaya Jawa yang meliputi: pengetahuan tentang gaya/cara berkomunikasi dalam budaya asal; penggunaan bahasa daerah dalam budaya Jawa; pengaruh mitos (sejarah budaya Jawa); orientasi nilai budaya Jawa; norma yang berlaku dalam budaya Jawa; dan simbol-simbol budaya Jawa. Dalam tahap ini ditekankan pada tahap abstract conceptualization. Subjek penelitian difasilitasi untuk mendefinisikan kembali karakteristik budaya Jawa dengan membandingkan pengetahuan yang 
dimiliki sebelumnya dan pengetahuan saat ini tentang budaya Jawa. Hasil yang diperoleh adalah subjek penelitian mampu mendeskripsikan pengetahuan yang dimiliki berkaitan dengan faktor penyebab sebuah perilaku dalam budaya Jawa.

\section{Terampil Berkomunikasi dalam Budaya Jawa}

Tahap ini bertujuan untuk meningkatkan keterampilan komunikasi subjek penelitian dalam konteks budaya Jawa yang meliputi keterampilan dalam: menerapkan gaya komunikasi yang sesuai dengan budaya Jawa; mampu membina hubungan empatik, dan mampu memberikan umpan balik secara akurat. Dalam tahap ini ditekankan pada tahap active experimentation. Pada tahap ini subjek penelitian diarahkan untuk menyaksikan video yang menampilkan proses komunikasi dalam budaya Jawa dan membandingkannya dengan hasil pengamatan atau pengalaman yang dilakukan oleh subjek penelitian berkaitan dengan pola komunikasi dalam budaya Jawa. Melalui hasil menyaksikan video dan hasil pengamatan yang dilakukan, subjek penelitian berhasil merumuskan langkah-langkah yang akan dilakukan dalam berkomunikasi dengan orang Jawa. Selanjutnya, subjek penelitian melakukan simulation exercise untuk mempraktikkan langkah-langkah yang telah dirumuskan dan didampingi oleh representasi orang Jawa untuk mengoreksi jika terdapat pola interaksi yang kurang tepat. Hasil yang diperoleh adalah subjek penelitian telah mampu menerapkan beberapa keterampilan komunikasi yang tepat berkaitan dengan gesture yang ditunjukkan dalam berkomunikasi, ungkapan atau perkataan yang digunakan dapat meningkatkan kedekatan dengan orang Jawa, dan perilakuperilaku tertentu yang tidak diperbolehkan ketika berkomunikasi.

\section{Deskripsi Analisis Data Statistik Setelah Diberikan Perlakuan}

Setelah diberi perlakuan, dilakukan pengukuran kembali untuk mengukur peningkatan skor kompetensi multikultural kelompok eksperimen dan kelompok kontrol dengan menggunakan analisis Wilcoxon Signed Rank Test. Hasil analisis Wilcoxon Signed Rank Test kemudian digunakan untuk menguji hipotesis.

Skor rata-rata kelompok eksperimen menunjukkan peningkatan yang lebih tinggi dibandingkan kelompok kontrol. Sebelum diberi perlakuan (pretest) skor rata-rata kelompok eksperimen sebesar 142,6, setelah diberikan perlakuan (posttest) skor rata-rata menjadi 234,1. Pada kelompok kontrol nilai rata-rata yang diperoleh sebelum diberikan perlakuan (pretest) sebesar 143,3 dan sesudah diberikan perlakuan (posttest) meningkat menjadi 164,3. Lebih besarnya nilai rata-rata kelompok eksperimen dibandingkan dengan nilai rata-rata kelompok kontrol menunjukkan bahwa model experiential learning efektif untuk meningkatkan kompetensi multikultural mahasiswa luar Jawa.

Pada kelompok kontrol terdapat satu subjek penelitian yang tidak mengalami peningkatan kompetensi multikultural secara signifikan. Walaupun demikian, perlakuan yang diberikan pada kelompok kontrol menunjukkan peningkatan signifikan berdasarkan nilai Asymp. Sig. (2-tailed) sebesar $0,008 \leq$ taraf nyata $(\alpha / 2=0,05)$. Berdasarkan hasil analisis Wilcoxon Signed Rank Test pada kelompok eksperimen, semua subjek penelitian mengalami peningkatan kompetensi multikultural secara signifikan dan dapat diketahui bahwa skor kompetensi multikultural kelompok eksperimen meningkat.

Selanjutnya, pengujian hipotesis menggunakan analisis Mann-Whitney U Test menunjukkan bahwa nilai uji Z sebesar -3,780 dan angka Asymp. Sig. (2-tailed) sebesar 0,000. Mengacu pada nilai Asymp. Sig. (2-tailed) yang lebih kecil dari taraf nyata $(\alpha / 2=0,05)$, maka dapat diketahui bahwa terdapat perbedaan skor posttest yang signifikan antara kelompok eksperimen dan kelompok kontrol, dimana skor kelompok eksperimen lebih besar dibandingkan dengan skor kelompok kontrol.

Berdasarkan hasil analisis Wilcoxon Signed Rank Test dan Mann-Whitney U Test yang telah dipaparkan, dapat diketahui bahwa terdapat peningkatan skor kompetensi multikultural yang signifikan setelah diberikan perlakuan (posttest) pada kelompok eksperimen dibandingkan sebelum diberikan perlakuan (pretest), dimana skor kelompok eksperimen lebih besar secara signifikan dibandingkan skor kelompok kontrol. 


\section{PEMBAHASAN}

Berdasarkan hasil uji statistik non-parametrik menggunakan analisis Mann Whitney U Test, hasil penelitian menunjukkan bahwa rerata skor kelompok eksperimen lebih tinggi dibandingkan dengan skor kelompok kontrol. Selain itu, rerata skor kompetensi multikultural mahasiswa luar Jawa pada kelompok eksperimen yang menerima perlakuan berupa pelatihan kompetensi multikultural menggunakan model experiential learning lebih tinggi dibandingkan kelompok kontrol yang menerima perlakuan berupa program peningkatan kompetensi multikultural.

Peningkatan kompetensi multikultural mahasiswa luar Jawa pada kelompok eksperimen tidak dapat dipisahkan dari pengaruh penerapan model experiential learning dalam proses penelitian. Keefektifan model experiential learning dalam meningkatkan kompetensi multikultural sebelumnya telah dibuktikan melalui beberapa penelitian lain yang menunjukkan bahwa teknik experiential learning sangat tepat untuk mengembangkan kompetensi budaya (cultural competency)(Arthur \& Achenbach, 2002; Green, 1995; Weaver, 1998). Model experiential learning juga dapat meningkatkan partisipasi aktif dari individu (peserta didik) untuk mengembangkan kesadaran terhadap perasaan; keyakinan; opini; dan sikap yang dimiliki kepada orang lain, kesadaran individu dapat membantu meningkatkan hubungan interpersonal antar-kelompok yang berbeda budaya secara positif (Denise \& Harris, 1989; Mok, 1999; Weaver, 1998).

Keefektifan model experiential learning dapat diperkuat dengan mengintegrasikan beberapa jenis kegiatan atau aktivitas yang sesuai dengan tujuan dari model experiential learning, yaitu proses pembelajaran yang menekankan pada konstruksi pengalaman sebagai hasil belajar individu. Pedersen (2000) juga mengintegrasikan beberapa teknik pembelajaran yang dapat digunakan untuk menstimulasi kesadaran multikultural individu, misalnya: field trip (kunjungan lapangan) pada budaya lain yang berada dalam komunitas masyarakat tertentu; menggali critical incidents (insiden atau kejadian penting) tentang masalah yang terjadi dalam konteks lintas budaya; mengamati pengalaman secara kultural yang dimiliki oleh orang-orang yang berbeda budaya; dan berdiskusi dengan narasumber (seseorang yang memiliki pemahaman memadai tentang budaya tertentu) dari kelompok masyarakat yang berbeda budaya. Aktivitas dalam setiap tahapan model experiential learning tidak selalu bersifat permanen melainkan dapat disesuaikan dengan tujuan penelitian yang akan dicapai dan karakteristik dalam setiap tahapan model experiential learning yang membentuk sebuah siklus.

Keunggulan dari model experiential learning tidak hanya menekankan pada aspek kesadaran multikultural semata, namun juga mampu meningkatkan aspek: pengetahuan (Karpudewan \& Mohd Ali Khan, 2017); komunikasi (Barron, Khosa, \& Jones-Bitton, 2017; Dernova, 2015); dan keterampilan (B. S. K. Kim \& Lyons, 2003) sebagai bagian integral dari kompetensi multikultural. Hal ini dibuktikan dari beberapa hasil penelitian lain yang menunjukkan bahwa model experiential learning efektif untuk meningkatkan kompetensi kultural individu tidak hanya dalam konteks keterampilan multikultural namun dalam bidang pribadi-sosial lainnya (Sperandio, GrudzinskiHall, \& Stewart-Gambino, 2010).

Meningkatnya kompetensi multikultural subjek penelitian dalam komponen kesadaran; pengetahuan; dan keterampilan multikultural berdasarkan hasil pengamatan selama proses perlakuan dengan menerapkan model experiential learning telah berimplikasi pada peningkatan kemampuan adaptasi subjek penelitian yang berasal dari budaya berbeda. Hal ini menunjukkan bahwa telah terjadi proses autoplastis, yaitu kemampuan individu untuk mengadaptasi dirinya sesuai dengan lingkungan budaya di sekitarnya ketika menghadapi situasi yang sulit atau perbedaan budaya.

Meningkatnya kompetensi multikultural juga mampu meningkatkan kualitas interaksi sosial di antara individu yang berbeda budaya. Tingkatan individu mencapai proses akulturasi tidak dapat lepas dari proses komunikasi secara langsung (proses interaksi) dengan orang lain yang berbeda budaya (Berry, 1999). Hal ini sangat relevan dengan tahapan dalam perlakuan yang diberikan untuk mempersiapkan subjek penelitian mampu berinteraksi dengan orang-orang dari budaya Jawa. Hal sama juga diperoleh dari penelitian lain (Y. Y. Kim, 2001; Repke \& Benet-Martínez, 2018), yang 
menunjukkan bahwa proses asimilasi dan akulturasi budaya sangat dipengaruhi oleh kemampuan individu dalam mengubah dan meningkatkan level kompetensi komunikasi dengan budaya setempat (host culture) dan mengembangkan integrasi sosial (social integration) dengan masyarakat setempat (host society). Hasil penelitian yang dipaparkan tersebut semakin menegaskan bahwa penerapan model experiential learning yang menekankan pada pola interaksi secara langsung antara mahasiswa luar Jawa dengan masyarakat Jawa menjadi faktor kunci yang memengaruhi peningkatan kompetensi multikultural mahasiswa luar Jawa di Kota Malang.

Keefektifan model experiential learning juga didukung dengan jenis kelompok yang digunakan, yaitu kelompok psikoedukasi yang menekankan pada fungsi pencegahan dan pengembangan dalam bidang pribadi-sosial. Penelitian yang berkaitan dengan penerapan kelompok psikoedukasi maupun karakteristik kelompok yang serupa dengan kelompok psikoedukasi juga dilakukan (LeBeauf, Smaby, \& Maddux, 2009). Penelitian tentang adaptasi keterampilan konseling untuk konseli multikultural menggunakan Skilled Counseling Training Model juga menerapkan serangkaian kegiatan dalam kelompok yang terdiri dari: modeling (pemodelan); mastery (pengusaan terhadap suatu keterampilan); persuasion (persuasi); arousal (semangat); dan supervisory feedback (umpan balik yang tersupervisi) dipandang efektif untuk meningkatkan keterampilan konselor dalam berinteraksi dengan konseli yang berasal dari latar belakang budaya yang beragam. Selain itu, kelompok kecil (small group) dalam model pelatihan Racial-cultural Counseling Competency juga dapat digunakan untuk meningkatkan self-exploration (eksplorasi diri) calon konselor (Carter, 2001).

Melalui dinamika kelompok, subjek penelitian dapat mengamati perilaku anggota kelompok lain; mengutarakan pandangan yang dimiliki; dan memperoleh pemahaman baru melalui proses berdiskusi dengan anggota kelompok lain dalam membahas topik yang menjadi fokus pembahasan kelompok. Selain itu, proses belajar dapat berlangsung secara simultan dan saling melengkapi di antara anggota kelompok. Melalui kelompok psikoedukasi, setiap subjek penelitian dapat belajar dengan mendayagunakan dinamika positif yang terjadi dalam kelompok dan membagi pengalaman serta keterampilan yang dimiliki, dan mampu meningkatkan kohesivitas antara anggota kelompok (Corey, Corey, \& Corey, 2013).

Rendahnya kompetensi multikultural memiliki beberapa dampak buruk, seperti adanya prasangka kepada orang lain yang berbeda budaya dan membentuk inklusivitas dalam kelompok ikatan primordial tertentu. Oleh sebab itu, ketika seorang individu memiliki kompetensi multikultural yang tinggi, mereka akan mampu mereduksi prasangka kepada kelompok yang berbeda budaya dan lebih terbuka untuk bergaul dengan orang-orang yang berbeda budaya.

\section{SIMPULAN}

Berdasarkan analisis data yang diperoleh, model experiential learning efektif untuk meningkatkan kompetensi multikultural mahasiswa luar Jawa di Kota Malang. Mahasiswa luar Jawa sebagai subjek penelitian mengalami peningkatan kesadaran dan pengetahuan multikultural yang berkaitan dengan: gaya atau cara komunikasi; bahasa; mitos (sejarah budaya); norma; orientasi nilai; dan simbol budaya dalam konteks budaya asal dan budaya Jawa. Kemampuan komunikasi subjek dengan individu atau kelompok dari budaya asalnya maupun budaya Jawa juga meningkat, hal ini ditunjukkan lewat ketepatan dan keakuratan dalam menginisiasi pembicaraan; mampu membina hubungan empatik; dan mampu secara efektif memberikan umpan balik (feedback) dalam percakapan. Terkait hasil penelitian, konselor pendidikan pada jenjang perguruan tinggi disarankan merancang program layanan bimbingan dan konseling yang bertujuan untuk memfasilitasi mahasiswa pada jenjang semester awal dalam beradaptasi dengan lingkungan budaya yang baru. Konselor pada jenjang perguruan tinggi dalam menerapkan model experiential learning perlu memperkuat kesadaran dan pengetahuan yang dimiliki oleh mahasiswa tentang budaya masyarakat setempat dengan cara mendatangi secara langsung komunitas budaya masyarakat tersebut sehingga pengalaman yang diperoleh lebih bersifat kontekstual dan faktual. Peneliti selanjutnya diharapkan mampu mengukur atau menilai secara akurat perubahan persepsi mahasiswa dalam memandang perbedaan budaya. 


\section{DAFTAR RUJUKAN}

Arswimba, A. A. (2016). Pengembangan Paket Pelatihan Kompetensi Multikultural bagi Mahasiswa. (Unpublished master's thesis). Universitas Negeri Malang.

Arthur, N., \& Achenbach, K. (2002). Developing Multicultural Counseling Competencies through Experiential Learning. Counselor Education and Supervision, 42(1), 2-14.

Barron, D., Khosa, D., \& Jones-Bitton, A. (2017). Experiential Learning in Primary Care: Impact on Veterinary Students' Communication Confidence. Journal of Experiential Education, 40(4), 349-365. https://doi.org/10.1177/1053825917710038

Berry, J. N. (1999). Culturally Competent Service. Library Journal, 124, 112-113.

Carter, R. T. (2001). Back to The Future in Cultural Competence Training. The Counseling Psychologist, 29(6), 787-789.

Corey, M. S., Corey, G., \& Corey, C. (2013). Groups: Process and Practice. Cengage Learning.

Damayanti, C., \& Kusumo, G. D. (2017). Pengembangan Modal Sosial Mahasiswa Luar Jawa di Universitas Slamet Riyadi. Research Fair Unisri, 1(2).

Denise, P. S., \& Harris, I. M. (1989). Experiential Education for Community Development. Westport, CT: Greenwood.

Dernova, M. (2015). Experiential Learning Theory as One of The Foundations of Adult Learning Practice Worldwide. Comparative Professional Pedagogy, 5(2), 52-57. https://doi.org/10.1515/ rpp-2015-0040

Downs, S. R. (1992). An Evaluation of Experiential Teaching/Learning Methods--In a Professional Legal Training Course. (Unpublished master's thesis). Macquarie University

Green, J. W. (1995). Cultural Awareness in The Human Services: A Multi-ethnic Approach. Prentice Hall.

Holcomb-McCoy, C. C., \& Myers, J. E. (1999). Multicultural Competence and Counselor Training: A National Survey. Journal of Counseling \& Development, 77(3), 294-302. https://doi. org/10.1002/j.1556-6676.1999.tb02452.x

Karpudewan, M., \& Mohd Ali Khan, N. S. (2017). Experiential-based Climate Change Education: Fostering Students' Knowledge and Motivation Towards The Environment. International Research in Geographical and Environmental Education, 26(3), 207-222. https://doi.org/10.1 080/10382046.2017.1330037

Kim, B. S. K., \& Lyons, H. Z. (2003). Experiential Activities and Multicultural Counseling Competence Training. Journal of Counseling \& Development, 81(4), 400-408. https://doi. org/10.1002/j.1556-6678.2003.tb00266.x

Kim, Y. Y. (2001). Becoming Intercultural: An Integrative Theory of Communication and Crosscultural Adaptation. Sage.

LeBeauf, I., Smaby, M., \& Maddux, C. (2009). Adapting Counseling Skills for Multicultural and Diverse Clients. Compelling Counseling Interventions: VISTAS, 33-42.

Mok, Y. F. (1999). Experiential Learning: Functional Attributes and Effectiveness. Studies in Continuing Education, 21(1), 57-72. https://doi.org/10.1080/0158037990210104

Pedersen, P. (2000). A Handbook for Developing Multicultural Awareness. American Association for Counseling.

Repke, L., \& Benet-Martínez, V. (2018). The (Diverse) Company You Keep: Content and Structure of Immigrants' Social Networks as a Window into Intercultural Relations in Catalonia. Journal of Cross-Cultural Psychology, 49(6), 924-944. https://doi.org/10.1177/0022022117733475

Reynolds, A. L., \& Pope, R. L. (1994). Perspectives on Creating Multicultural Campuses. Journal of American College Health, 42(5), 229-233. 
Riskiyah. (2014). Pengembangan Paket Pelatihan Konseling Kelompok Kognitif Behavioral Berbasis Experiential Learning untuk Instruktur Bimbingan dan Konseling. (Unpublished master's thesis). Universitas Negeri Malang.

Rustanto, B. (2015). Masyarakat Multikultur di Indonesia. Bandung: Remaja Rosdakarya.

Sabnani, H. B., Ponterotto, J. G., \& Borodovsky, L. G. (1991). White Racial Identity Development and Cross-cultural Counselor Training: A Stage Model. The Counseling Psychologist, 19(1), $76-102$.

Sperandio, J., Grudzinski-Hall, M., \& Stewart-Gambino, H. (2010). Developing an Undergraduate Global Citizenship Program: Challenges of Definition and Assessment. International Journal of Teaching and Learning in Higher Education, 22(1), 12-22.

Sue, D. W. (1991). A Model for Cultural Diversity Training. Journal of Counseling \& Development, 70(1), 99-105. https://doi.org/10.1002/j.1556-6676.1991.tb01568.x

Weaver, H. N. (1998). Teaching Cultural Competence: Application of Experiential Learning Techniques. Journal of Teaching in Social Work, 17(1-2), 65-79. 